\title{
Dynamics between Digital Visibility through Social Media Marketing and Crowdfunding: Path to Succeed in Entrepreneurship
}

\author{
Girish G P PhD \\ Associate Professor (Finance) \\ ICFAI Business School (IBS) \\ Bengaluru, India \\ E-mail: gpgirish.ibs@gmail.com \\ Seeboli Ghosh $P h D$ \\ Faculty Member (Marketing) \\ ICFAI Business School (IBS) \\ Bengaluru, India
}

Received: July 07, 2020

Accepted: July 20, 2020

Online Published: August 07, 2020

URL: https://doi.org/I0.4628I/ijfb.v4i2.698

\begin{abstract}
Digital visibility through social media marketing has played a colossal role in the realm of entrepreneurship and fundraising. Strong positive dynamics between social media marketing and crowd-funding has the impending to decipher demand-supply gap of fundraising at the pre-seed stage. In this study, we explore the relationship between usage of social media and awareness of crowd-funding as a viable option for raising pre-seed capital in an emerging market of India which has witnessed the exponential growth of start-up companies and entrepreneurship in the past few years. The results of the study suggest that awareness of different options of crowdfunding for raising pre-seed capital is strongly correlated with the effective usage of social media platforms by the organizations. From an organization's perspective, it has been found that effective use of Social Media platforms increases with the duration involved in social media platforms. The results of the study give a perspective for all entrepreneurs, fundraisers, and start-up companies that how digital visibility through social media marketing can unravel the problem of crowd-funding. With a growing trend of today's youth using social media marketing worldwide, the strong dynamics between crowd-funding and social media marketing is expected to breed exponentially in terms of their contribution to the economy, wealth generation, and job creation.
\end{abstract}

\section{Keywords: Social Media Marketing, Digital Visibility, Crowdfunding, Fundraising, Entrepreneurship, India.}

\section{Introduction}

Start-up culture in India has been a significant contributor in terms of wealth generation, job creation and has made a significant contribution to India's GDP in the last few years. India ranks $3^{\text {rd }}$ in the global start up ecosystem (Economic Survey, 2019) with an awe-inspiring fact that start-ups have raised about $\$ 7.5$ billion in funding in 2018 as against $\$ 4.3$ billion in 2017. The role played by digital and social media marketing in the evolution of the start-up ecosystem has been imperative. Though the social media revolution has ensured relatively easy access to get funds, however, there still exists a gap between demand and supply to raise capital at the pre-seed (Mollick, 2013). For a start-up revolution to continue progressing and thriving, pre-seed capital becomes an important dimension to consider. It's a well-known fact that raising capital is not easy for Start-ups which are in their nascent stage. At this juncture, companies can consider crowd-funding which has already proved its importance in the context of developed nations and the social media revolution is making it even more significant from the perspective of a developing country like India.

Crowd-funding may be outlined as "the effort" undertaken "by entrepreneurial people and groups - cultural, social and for-profit - to fund their ventures by drawing on comparatively small" financial "contributions from a comparatively sizable number of individuals, without using standard monetary intermediaries”(Allison, Davis, Short, \& Webb, 20I4). It has also been witnessed that India has a significantly high exit for a large number of start-up organizations example: In Bangalore city which is considered as the start-up capital of India has witnessed a significantly higher number of exit for a new age organizations' in the past few years. Studies have indicated that the key reason behind this exit has been difficulties in raising funds at the pre-seed stage for the start-ups. It has been found that though there are different modes of raising capital from angel investors, venture capitalists and bank loans which are available in the market, yet, these options are not always effective enough to raise pre-seed capital. Crowd-funding as a mode of finance has the potential to bridge the demand and supply gap for the Indian Start-up at the nascent stage of the business (Belleflamme, 20I3) that ultimately helps in improving start-ups exit. 
In this study, we explore the relationship between usage of social media and awareness of crowd-funding as a viable option for raising pre-seed capital in an emerging market of India which has witnessed exponential growth of start-up companies and entrepreneurship in the past few years. The results of the study give a perspective for all entrepreneurs, managers and start-up companies who would like to explore crowd-funding as a source of finance in an emerging market like India and its linkage with social media marketing. With a growing trend of today's youth embracing entrepreneurship world-wide, the role played by crowd-funding and social media marketing is expected to grow exponentially in terms of their contribution to the economy, wealth generation and job creation. The rest of the paper is structured as follows. In Section 2 we review literature pertaining to social media marketing and crowd-funding and highlight the gaps identified in the literature. In Section 3 we elucidate the main objective of this study, Research Methodology, and Hypothesis formulated for our study and in Section 4 we present our empirical findings and discuss the implication and conclude our study in Section 5.

\section{Literature Review}

The development and augmentation of Small and Medium Enterprises (SMEs) in any economy is awfully dependent on the entrepreneurs' access to monetary resources. Studies in entrepreneurial finance elucidate that one of the foremost factors of start-ups' failure is the lack of adequate funds in. SMEs are predominantly funded by internal funding and external funding from business angels, venture capitalists, banks, companies and governmental organizations (Block, Vries, Schumann, \& Sandner, 2013). Crowdfunding is believed to narrow down a funding gap within entrepreneurial finance by offering another avenue to explore funding (Heminway, 2014). Crowd-funding may be outlined as "the effort" undertaken "by entrepreneurial people and groups - cultural, social, and for-profit - to fund their ventures by drawing on comparatively small" financial "contributions from a comparatively sizable number of individuals, without using standard monetary intermediaries" (Agrawal, Catalini, \& Goldfarb, 2013). Since crowd-funding relates to wide-ranging projects and is employed for an assortment of functions, its current definition seems exceedingly "constant evolutionary flux" and is perceived to be arbitrary and discretionary (Mollick, 20I4). Crowd-funding incorporates the origin of funding activities by assembling small amounts of money from a large number of individuals which has existed for hundreds of years and has perpetually been a founding concept in charity. Some of the well-known examples include a) Mozart and Beethoven, who supported their manuscripts and concerts with cash collected from music enthusiasts b) Development of the Statue of Liberty in New York c) Construction of the Nordic Museum in Stockholm and d) Elections of President Obama in the United States of America (Agrawal, Catalini, \& Goldfarb, 20I I).

Crowd-funding in its modern form has been shaped by an acute shortage of external entrepreneurial finance and simultaneous development of Web 2.0 technology - internet application that has simplified communication and fostered collaboration thereby bridging and bringing together team of people with common interests (Belleflamme, Lambert, \& Schwienbacher, 2010; Kleeman, Vob, \& Rieder, 2008). Crowdfunding sourcing is a participative online activity within which an individual, an establishment, a non-profit organization, or a corporation proposes to a bunch of people of varying data, non-uniformity and number via a flexible open the decision, the voluntary undertaking of a task (Gerber, Hui, \& Kuo, 2012). The term of crowd sourcing was at the outset coined in 2006 in a well-known journal Wired by the editor and journalist Jeff Howe. Some studies in literature dispense the origin of crowdsourcing occurrence to a change from a firmdriven to customer-driven production method and R\&D created mutual advantages for both the firms and their customers. Other studies connect the origin of the crowdsourcing with the event of internet and network areas. According to Buttice, Colombo, and Wright (2017), crowdsourcing is perceived as a result of a lot of substantial transition from industrial data economy, characterized by centralization, skilled labour and capital-intensity, to a networked data economy, that leans in the direction of cooperative problem-solving and democratization of innovation The nature of crowdfunding may be outlined as "crowdsourced financing" (Buttice et al., 2017 ), that comes from a large range of skilled and unprofessional people and is used for supporting varied entrepreneurial and corporate activities. Choy and Schlagwein (2016) impelled that crowdsourcing and crowdfunding are related concepts which build sharing economy linking exchange of slack resources both on a local and global scale through the digital platforms that replace third-party intermediaries. In their paper Lynda and Black (2018), tried to evaluate US legislation pertaining to equity crowdfunding. They came up with a conceptual model, demonstrating how crowdfunding has the potential to transform the scope of equity financing continuum which indicates a new avenue of raising capital. Andreas, Merete, and Kalanit (2019) mentioned in their research paper that investors to entrepreneurs can be segregated into two ways: inward benefits and outward benefits. Furthermore, they identified that personal gain is associated with investors' participation in crowdfunding activities (Andreas et al., 2019).

According to literature, different ways of crowdfunding can be categorized under a) Loan-based crowdfunding (also referred to as crowdlending): With the help of crowd loaning, people (P2P-lending) and mature firms (P2B-lending) might search funding without any money intermediary, for example, banks. In exchange for funds, lenders receive interest rate payments, which need to be paid out at a preliminary determined payment schedule (Allison et al., 20I4). Berkovich (20I I) elucidated that this sort of crowdfunding should be considered as social lending. In the case of P2B-lending, lenders and borrowers may also agree upon a share of the firm's earnings, which will serve as an alternative to interest payments and can be paid out to the lender at the end of the lending period. In either case, lenders bear risks and receive compensations corresponding to the risks are undertaken (Berkovich, 201I). b) Equity-based crowdfunding (also referred to as crowd investing): Equity-based crowdfunding permits entrepreneurs to accumulate further capital by selling a specific number of shares with or without voting rights to both accredited and non-accredited investors. The investments in equity-based 
crowdfunding are collected throughout the indicated funding period and are typically transferred right after the funding round is closed (Everett, 2010). This kind of crowdfunding is considered to be the most complicated instrument among the crowdfunding alternatives not only due to the complexity of the method of equity issue itself but however also due to its high dependence on various sorts of national and international legislation. c) Crowdfunding and social media: Several studies have shown that social capital can increase possibilities of success in crowdfunding projects. There's corroboration of connection between the success of start-up projects and social ties (Buttice et al., 2017). Predominantly studies in entrepreneurship have established that family and friends are necessary sources of seed capital for start-ups (Agrawal et al., 20I I). Dominik, Nikolaus, Philipp, and Jan (2020), in their paper highlighted how entrepreneurial cognition process can be enhanced through collective intelligence and crowdsourcing. Furthermore they also identified that opportunities can be created from interactions between entrepreneurs and their social environment (Dominik et al., 2020).

Mihardjo, Sasmoko, Alamsjah, and Elidjen (2019) elucidated that digital transformation plays a significant role in shaping digital business capability and argued with a model that supported the importance of digital transformation in different business scenarios (Mihardjo et al., 2019). Bawre and Kar (2019) in their study explored to what extent Indian Financial Institutes use social media platforms for different purposes including financial awareness generating. This contemporary study gave a detailed insight on social media usage in terms of cost reduction and customer satisfaction.

Burtch, Ghose, and Wattal (2013) elucidated that use of social media technologies in the domain of crowdfunding makes the crowdfunding activity transparent for all the consumers Burtch et al., (2013). The study by Mollick and Nanda (2016) established a correlation between Facebook friends and crowdfunding projects' success. The analysis was based on a sample of Kickstarter projects in a film category with the target of not less than 5000 dollars and it was found that a project creator with ten Facebook friends has a nine percent chance of success, one with one hundred friends has a twenty percent chance of success, and one with one thousand friends has a forty percent chance of success (Mollick \& Kuppuswamy, 20I4). The study botched to take under deliberation "likes" and failed to take in projects launched by the creators who don't have any Facebook account. Kaplan and Haenlein (2010), identified different principles that channelize an effective campaign by using different tools of social media helping in predicting expected outcomes, predominantly how popular a project will be in the mind of target segment and which projects have possibility to become successful and meet fundraising goals. Hekman and Brussee (2013) in their study found significant correlation between the activities of crowdfunding and social media seals of approval. They found that "likes" play very significant role in case of fundraising activities: for example ratio of funding, the total fundraised and the number of backers. It was also found that without a considerable number of "likes", there would be a high chance that the project target will not be delivered (Hekman \& Brussee, 20I3).

Robiady, Windasari, and Nita (2020) in their study explored different effects of direct vs. indirect storytelling techniques creating an impact on social-issue crowdfunding campaigns. The study indicated that storytelling techniques have a significant positive impact on customer engagement and donation performance explicitly benefited from direct storytelling technique. However, customer engagement does not serve as a mediator between storytelling and donation performance. The study was based on the research gap concerning digital customer engagement predominantly in the social purpose context (Robiady et al., 2020).

Most of the studies in the literature have been deliberated from a developed economy's perspective while exploring crowdfunding and entrepreneurial finance. Studies related to Crowdfunding from an emerging economy's perspective is very few and sporadic. The fact that start-up culture in India has been a significant contributor in terms of wealth generation, job creation and has made a significant contribution to India's GDP in the last few years makes a strong case for exploring this dimension of crowd-funding and entrepreneurial finance. India ranks $3^{\text {rd }}$ in the global star up ecosystem (Economic Survey, 2019) with an awe-inspiring fact that start-ups have raised about $\$ 7.5$ billion in funding in 2018 as against $\$ 4.3$ billion in 2017. The role played by digital and social media marketing in the evolution of the start-up ecosystem has been imperative.

\section{Research Methodology and Hypothesis}

Most of the studies related to crowdfunding literature are based on the demand-supply gap. Very few studies have tried to explore the linkage between social media and crowdfunding. In this study we explore the relationship between the usage of social media and awareness of crowd-funding as a viable option for raising pre-seed capital in an emerging market of India which has witnessed the exponential growth of start-up companies and entrepreneurship in the past few years. The study investigates the dynamics between the organization's effective use of social media platform and the duration involved in the social media platforms. Further, we would also investigate the relation between duration the organization is using social media platforms and the awareness of different options of crowdfunding to raise pre-seed capital.

Research is designed in such a way that it comprises of two-stages. In Stage I exploratory research is used as a tool by the researcher to identify precision about the problem under study. Exploratory research has been conducted using a) Qualitative research involving in-depth focus group interview and b) survey based on data collected from budding entrepreneurs of Bangalore, India. To be more precise, owners/ partners of the start-ups/ ventures were considered as the population of the study. Bangalore is known as start up hub in India and that was the reasons for selecting Bangalore for conducting the study. The sample adequacy test was incorporated and the required the sample size was found to be 288 as per Nargundkar's method. 


\section{I Hypothesis I}

Social Media has been one of the strong drivers of creating networks and has infused knowledge to diverse set of individuals including budding entrepreneurs and start-ups. Seminars, webinars, knowledge conclaves, trade events by industrial bodies leveraging liaising between the individuals and imparting knowledge and mentorship on the different ways of crowdfunding has been at the forefront. We believe effective use of social media and being active in these networks provides required awareness and knowledge of crowdfunding as a viable option to pre seed capital.

- Ho: There is no difference in the Score in terms of the effective use of Social Media platform by the respondents of the different organizations having different levels of awareness of crowdfunding as a viable option to pre-seed capital.

- $\mathrm{H}_{\mathrm{r}}$ : There is a significant difference in the Score in terms of the effective use of Social Media platform by the respondents of the different organizations having different levels of awareness of crowdfunding as a viable option to pre-seed capital.

\subsection{Hypothesis II}

Social media has been sprouting with multiple groups and networks shaped for specific reasons with free access to different resources and knowledge. The challenge is linking the right groups based on the requirement. Longer the duration of an organization is being active in the social network is believed to strengthen attracting pertinent entities and being connected with the right groups and networks. This would lead the organization in the direction of more effective use of social media for any kind of campaign, recruitment, sales and brand building exercise.

- $\mathrm{H}_{0}$ : There is no difference in the Score in terms of the organization's effective use of Social Media platform by the respondents whose organization is using the social media for a different duration ( $\mathrm{I}-2$ years, $2-3$ years, $3-5$ years, 5 + years).

- $\mathrm{H}_{\mathrm{r}}$ : There is a significant difference in the Score in terms of the organization's effective use of Social Media platform by the respondents whose organization is using social media for a different duration (I-2 years, 2-3 years, $3-5$ years, $5+$ years $)$.

\subsection{Hypothesis III}

Social Media has been one of the strong drivers of creating networks and infuses knowledge to a diverse set of individuals including budding entrepreneurs and start-ups. Today, many knowledge-sharing webinars, networks are leveraging liaising and mentorship of budding entrepreneurs and new age ideas (like strategy, potential clients, modes of angel investment and raising pre-seed capital etc). We believe, the longer duration of an organization is active in the social network might help in attracting other relevant entities and being connected with the right groups and networks leading to more effective use of social media in terms of the campaign, recruitment, sales and brand building. As social media buzz increases with duration of time, we believe there is a high probability of garnering the knowledge and the resource required to raise pre-seed capital for the organization and formulate the following Hypothesis.

- $\mathrm{H}_{0}$ : There is no association between the duration the organization is using the social media platforms and the awareness of the different options of crowdfunding to raise pre-seed capital.

- $\mathrm{H}_{\mathrm{I}}$ : There is an association between the duration the organization is using the social media platforms and the awareness of the different options of crowdfunding to raise pre-seed capital.

\section{Empirical Findings}

\section{I For Hypothesis I [Different Levels of Awareness]}

The score for the different hypothesis is obtained by adding up the scores of all the parameters of a dimension that have been capture using a 5-point scale Likert score through Questionnaire. Table I highlights the Score on the perception of crowdfunding as a feasible mechanism of raising pre-seed capital. The mean, median and mode values are close by and almost similar and Tests of Normality as given in Table 2 highlights that samples are normally distributed thereby ensuring that the sample is representative and adequate for carrying out the inferential statistics. Table 3 highlights the Descriptive statistics (ANOVA) of our data collected where Different levels of awareness of crowdfunding as a feasible option to raiseseed capital (categorical Variable) in our Independent variable and Score is our dependent variable. 
Table I. Score on the perception of crowdfunding as of feasible mechanism of raising pre-seed capital

\begin{tabular}{llll}
\hline \multicolumn{4}{c}{ Basic Statistical Measures } \\
\hline Location & \multicolumn{3}{l}{ Variability } \\
\hline Mean & 19.20 & Std Deviation & 0.98 \\
\hline Median & 20.00 & Variance & 0.96 \\
\hline Mode & 20.00 & Range & 2.00 \\
\hline & & Inter-quartile Range & 2.00 \\
\hline
\end{tabular}

Table 2. Tests of Normality

\begin{tabular}{cccccc}
\hline \multicolumn{3}{c}{ Kolmogorov-Smirnov } & \multicolumn{3}{c}{ Shapiro-Wilk } \\
\hline Statistic & $\mathrm{df}$ & Sig. & Statistic & $\mathrm{df}$ & Sig. \\
\hline .393 & 500 & .120 & .622 & 500 & .080 \\
\hline \\
test of normality has the following hypothesis.HO:
\end{tabular}
Thally distributed.

Note: Kolmogorov- Smimov test of normality has the following hypothesis.HO: The samples are normally distributed and HI: The samples are not normally distributed.

Table 3. Descriptive Statistics (ANOVA) for different levels of awareness

\begin{tabular}{|c|c|c|c|c|c|c|c|c|}
\hline & \multirow[t]{2}{*}{$\mathrm{N}$} & \multirow[t]{2}{*}{ Mean } & \multirow{2}{*}{$\begin{array}{c}\text { Std. } \\
\text { Deviation }\end{array}$} & \multirow{2}{*}{$\begin{array}{l}\text { Std. } \\
\text { Error }\end{array}$} & \multicolumn{2}{|c|}{$95 \%$ Confidence Interval for } & \multirow[t]{2}{*}{ Minimum } & \multirow[t]{2}{*}{ Maximum } \\
\hline & & & & & Lower Bound & Upper Bound & & \\
\hline $\mathrm{I}$ & 50 & 84.16 & 5.203 & .736 & 82.68 & 85.64 & 74 & 98 \\
\hline 2 & 50 & 74.26 & 2.337 & $.33 \mathrm{I}$ & 73.60 & 74.92 & 68 & 80 \\
\hline 3 & 100 & 45.33 & 3.485 & .348 & 44.64 & 46.02 & 40 & 50 \\
\hline 4 & I50 & 31.56 & 4.359 & .356 & 30.86 & 32.26 & 25 & 39 \\
\hline 5 & 150 & 15.00 & 3.234 & .264 & $\mathrm{I} 4.48$ & 15.52 & 10 & 20 \\
\hline Total & 500 & 38.88 & 23.262 & $\mathrm{I} .040$ & 36.83 & 40.92 & I0 & 98 \\
\hline
\end{tabular}

Table 4. Empirical Outcome from ANOVA for different levels of awareness

\begin{tabular}{cccccc}
\hline & Sum of Squares & Df & Mean Square & F & Sig. \\
\hline Between Groups & 262836.902 & 4 & 65709.226 & 4526.682 & .000 \\
\hline Within Groups & 7185.410 & 495 & I4.516 & & \\
\hline Total & 270022.312 & 499 & & & \\
\hline
\end{tabular}

Table 4 presents the results from Anova test. The p-value of 0.000 less than 0.05 (the benchmarked $95 \%$ confidence level or $5 \%$ significance level) statistically suggests focusing on the alternate hypothesis that there is a significant difference in the score in terms of the effective use of Social Media platform by the organization by the respondents of different levels of awareness of crowdfunding as a viable option to pre-seed capital. The Tukey Pairwise Test or Tukey HSD (Honestly Significant Difference) The test is incorporated with the ANOVA test above for further investigating where does, the difference lies all the five categories (in terms of the agreement to the statement that they are fully aware of the different avenues of crowdfunding as a feasible option to raise capital) as far as their scores were given to their organizations. If the pvalue is less than 0.05 (95\% confidence or 5\% significance) while comparing between the categories, it is confirmed that there is a significant difference between the two categories. Table 5 highlights result from Tukey Pairwise Test and statistically suggest that there is a significant difference in scores between all the five categories (in terms of the agreement to the statement that they are fully aware of the different avenues of crowdfunding as a feasible option to raise capital) as far as their scores were given to their organizations of how effectively they were using the Social Media Platforms.

Table 5. Multiple Comparisons from Tukey Pairwise Test for different levels of awareness

\begin{tabular}{cccccccc}
\hline & & Mean Difference & Std. Error & Sig. & \multicolumn{2}{c}{ 95\% Confidence Interval } \\
\cline { 5 - 7 } & & & & & Lower Bound & Upper Bound \\
\hline $\begin{array}{c}\text { Tukey } \\
\text { Pairwise }\end{array}$ & $\mathrm{I}$ & 2 & $-21.886^{*}$ & 0.588 & 0 & -23.4 & -20.37 \\
\cline { 2 - 7 } & 3 & $-56.709^{*}$ & 0.876 & 0 & -58.97 & -54.45 \\
\hline
\end{tabular}




\begin{tabular}{|c|c|c|c|c|c|c|c|}
\hline \multirow[t]{10}{*}{ Test } & & 4 & $-67.648^{*}$ & 1.008 & $\overline{0}$ & -70.25 & -65.05 \\
\hline & 2 & I & $21.886^{*}$ & 0.588 & 0 & 20.37 & 23.4 \\
\hline & & 3 & $-34.823^{*}$ & 0.879 & 0 & -37.09 & -32.56 \\
\hline & & 4 & $-45.762^{*}$ & I.OI & 0 & -48.37 & -43.16 \\
\hline & 3 & $\mathrm{I}$ & $56.709^{*}$ & 0.876 & 0 & 54.45 & 58.97 \\
\hline & & 2 & $34.823^{*}$ & 0.879 & 0 & 32.56 & 37.09 \\
\hline & & 4 & $-10.939^{*}$ & I.20I & 0 & $-\mathrm{I} 4.03$ & -7.84 \\
\hline & 4 & I & $67.648^{*}$ & 1.008 & 0 & 65.05 & 70.25 \\
\hline & & 2 & $45.762^{*}$ & I.OI & 0 & 43.16 & 48.37 \\
\hline & & 3 & $10.939^{*}$ & I.20I & 0 & 7.84 & I4.03 \\
\hline
\end{tabular}

*. The mean difference is significant at the 0.05 level.

Table 6 showcases result from the test of homogeneous subsets highlighting which groups have the same mean and which one has a different mean. The results showcases that the respondents, who have strongly agreed to the fact that they are aware of the different options of crowdfunding as raising pre-seed capital, have given significant high scores compared to others in terms of their organization effectively using social media platforms (average score being 84.16 on a scale of I00). The second highest score is provided by respondents who agree to the fact that they are aware of different options of crowdfunding as raising pre-seed capital have given significant high scores compared to others in terms of their organization effectively using social media platforms (average the score being 74.26 on a scale of 100 ). This is followed by respondents who are neutral (average score being 45.33), respondents who disagree (average score being 3I.56) and respondents who strongly disagree (average score being I5.00) as far as being aware of the different options of crowdfunding as rising preseed capital.

Table 6. Test of Homogeneous Subsets for different levels of awareness

\begin{tabular}{|c|c|c|c|c|c|c|}
\hline \multirow{2}{*}{\multicolumn{2}{|c|}{$\mathrm{N}$}} & \multicolumn{5}{|c|}{ Subset for alpha $=0.05$} \\
\hline & & $\mathrm{I}$ & 2 & 3 & 4 & 5 \\
\hline 5 & 150 & 15.00 & & & & \\
\hline 4 & 150 & & 31.56 & & & \\
\hline 3 & 100 & & & 45.33 & & \\
\hline 2 & 50 & & & & 74.26 & \\
\hline $\mathrm{I}$ & 50 & & & & & 84.16 \\
\hline Sig. & & 1.000 & 1.000 & 1.000 & 1.000 & 1.000 \\
\hline 5 & $\mathrm{I} 50$ & I5.00 & & & & \\
\hline 4 & 150 & & 31.56 & & & \\
\hline 3 & 100 & & & 45.33 & & \\
\hline 2 & 50 & & & & 74.26 & \\
\hline $\mathrm{I}$ & 50 & & & & & 84.16 \\
\hline
\end{tabular}

\subsection{For Hypothesis 2 [Effective Use of Social Media Platform]}

Table 7 highlights the Descriptive statistics (Anova) where Duration of the organization using social media (Categorical Variable) in the Independent variable and Score is the dependent variable. Score refers to the perception of crowdfunding as of feasible mechanism of raising pre-seed capital. Table 8 highlights the results from the Test of ANOVA for Effective use of Social Media Platform. The p-value of 0.000 less than 0.05 (the benchmarked $95 \%$ confidence level or $5 \%$ significance level) propels us to zero in on the alternate hypothesis that there is a significant difference in the score in terms of the organization's effective use of Social Media platform by the respondents whose organization is using the social media for a different duration ( $\mathrm{I}-2$ years, $2-3$ years, $3-5$ years, $5+$ years).

Table 7. Descriptive Statistics (ANOVA) for Effective use of Social Media Platform

\begin{tabular}{|c|c|c|c|c|c|c|c|c|}
\hline & \multirow[t]{2}{*}{$\mathrm{N}$} & \multirow[t]{2}{*}{ Mean } & \multirow{2}{*}{$\begin{array}{c}\text { Std. } \\
\text { Deviation }\end{array}$} & \multirow{2}{*}{$\begin{array}{l}\text { Std. } \\
\text { Error }\end{array}$} & \multicolumn{2}{|c|}{$95 \%$ Confidence Interval for } & \multirow[t]{2}{*}{ Minimum } & \multirow[t]{2}{*}{ Maximum } \\
\hline & & & & & Lower & Upper & & \\
\hline $\mathrm{I}$ & 203 & I8.08 & $5.94 \mathrm{I}$ & .417 & 17.26 & I8.9I & I0 & 30 \\
\hline 2 & 198 & 39.97 & 6.765 & $.48 \mathrm{I}$ & 39.02 & 40.92 & 30 & 68 \\
\hline
\end{tabular}




\begin{tabular}{ccccccccc}
\hline 3 & 58 & 74.79 & 2.246 & .295 & 74.20 & 75.38 & 70 & 78 \\
\hline 4 & $4 \mathrm{I}$ & 85.73 & 4.348 & .679 & 84.36 & 87.10 & 80 & 98 \\
\hline Total & $\mathbf{5 0 0}$ & $\mathbf{3 8 . 8 8}$ & $\mathbf{2 3 . 2 6 2}$ & $\mathbf{1 . 0 4 0}$ & $\mathbf{3 6 . 8 3}$ & $\mathbf{4 0 . 9 2}$ & $\mathbf{1 0}$ & $\mathbf{9 8}$ \\
\hline
\end{tabular}

Table 8. Empirical Outcome from ANOVA for Effective use of Social Media Platform

\begin{tabular}{cccccc}
\hline & Sum of Squares & Df & Mean Square & F & Sig. \\
\hline Between Groups & $252833.35 \mathrm{I}$ & 3 & 84277.784 & $243 \mathrm{I} .897$ & .000 \\
\hline Within Groups & I7I88.96I & 496 & 34.655 & & \\
\hline Total & $270022.3 \mathrm{I} 2$ & 499 & & & \\
\hline
\end{tabular}

Table 9 highlights the results from the test of homogeneous subsets showing which groups have the same mean and which one has different means. The results suggest that there is a significant difference by the respondents between all the four categories (in terms of different durations the organization is involved in social media platforms) as far as their scores were given to their organizations of how effectively they were using the Social Media Platforms. The respondents who proclaim that the organization is involved in social media platforms for more than 5 years are the one who has given the highest score to their organization in terms of effectively using the social media platforms (average score of 85.73). This is followed by the respondents stating that the organization is involved in 3-5 years in the social media platforms (average score in terms of effectively using the social media platform is 74.69). The third-highest score is incorporated by respondents stating that the organization is involved in 2-3 years in the social media platforms (average score in terms of effectively using the social media platform is 39.97 ) followed by respondents stating that the organization is involved in I-2 years in the social media platforms (average score in terms of effectively using the social media platform is I8.08).

Table 9. Test of homogeneous subsets for Effective use of Social Media Platform

\begin{tabular}{|c|c|c|c|c|c|}
\hline & \multirow[t]{2}{*}{$\mathrm{N}$} & \multicolumn{4}{|c|}{ Subset for alpha $=0.05$} \\
\hline & & $\bar{I}$ & 2 & 3 & $\overline{4}$ \\
\hline $\mathrm{I}$ & 203 & I8.08 & & & \\
\hline 2 & 198 & & 39.97 & & \\
\hline 3 & 58 & & & 74.79 & \\
\hline 4 & $4 \mathrm{I}$ & & & & 85.73 \\
\hline Sig. & & I & $\mathrm{I}$ & $\mathrm{I}$ & I \\
\hline $\mathrm{I}$ & 203 & 18.08 & & & \\
\hline 2 & 198 & & 39.97 & & \\
\hline 3 & 58 & & & 74.79 & \\
\hline 4 & $4 \mathrm{I}$ & & & & 85.73 \\
\hline
\end{tabular}

\subsection{For Hypothesis 3 [Association between the Duration of Using Social Media Platforms and Awareness of Different Options of Crowd Funding]}

Table IO highlights Case Processing Summary for Association between the duration of using social media platforms and awareness of different options of crowd funding. Table II highlights Results from Cross Tabulation. Table below highlights Results from Chi-Square Tests and Association Analysis. Table I2 highlights Results from Chi Square Test where the Independent Variable is Duration the organization is using the social media platforms (4 levels)-Categorical and The dependent variable is The extent of agreeing to the fact of being aware of the different options of crowdfunding to raise pre-seed capital ( 5 levels) -Categorical. The asymptotic assumption is satisfied as $90 \%$ of the cells in Chi-Square Test have a value of 5 or more compared to the benchmark of at least $80 \%$ of the cells must have a value of 5 or more. Thus, the chi-square test is justified.

Table I0. Case Processing Summary for Association between the duration of using social media platforms and awareness of different options of crowdfunding

\begin{tabular}{|c|c|c|c|c|c|c|}
\hline \multirow{3}{*}{$\begin{array}{l}\text { Case Processing } \\
\text { Summary }\end{array}$} & \multicolumn{6}{|c|}{ Cases } \\
\hline & \multicolumn{2}{|c|}{ Valid } & \multicolumn{2}{|c|}{ Missing } & \multicolumn{2}{|c|}{ Total } \\
\hline & $\mathrm{N}$ & Percent & $\mathrm{N}$ & Percent & $\mathrm{N}$ & Percent \\
\hline & 500 & $100.0 \%$ & 0 & $0.0 \%$ & 500 & I00.0\% \\
\hline
\end{tabular}


Table II. Cross Tabulation for Association between the duration of using social media platforms and awareness of different options of crowdfunding

\begin{tabular}{cccccc}
\hline & \multicolumn{4}{c}{ Count } & Total \\
\cline { 2 - 5 } & $\mathrm{I}$ & 2 & 3 & 4 & \\
\hline $\mathrm{I}$ & 0 & 0 & $\mathrm{I} 0$ & 40 & 50 \\
\hline 2 & 0 & $\mathrm{I}$ & 48 & $\mathrm{I}$ & 50 \\
\hline 3 & 0 & $\mathrm{I} 00$ & 0 & 0 & $\mathrm{I} 00$ \\
\hline 4 & 53 & 97 & 0 & 0 & $\mathrm{I} 50$ \\
\hline 5 & $\mathrm{I} 50$ & 0 & 0 & 0 & $\mathrm{I} 50$ \\
\hline Total & 203 & $\mathrm{I} 98$ & 58 & $4 \mathrm{I}$ & 500 \\
\hline
\end{tabular}

Table I2. Results from Chi-Square Tests for Association between the duration of using social media platforms and awareness of different options of crowd funding

\begin{tabular}{cccc}
\hline & Value & df & Asymp. Sig. (2-sided) \\
\hline Pearson Chi-Square & I I3I.530 & I2 & .000 \\
\hline Likelihood Ratio & 923.315 & $\mathrm{I} 2$ & .000 \\
\hline Linear-by-Linear Association & 433.708 & $\mathrm{I}$ & .000 \\
\hline $\mathrm{N}$ of Valid Cases & 500 & & \\
\hline 2 cells (I0.0\%) have expected count less than 5. (Asymptotic assumptions) \\
\hline
\end{tabular}

The chi square test requires that at least $75 \%$ of the cell values must have a value of more than 5 or more or at the most $25 \%$ of the cells can have a value of less than 5 . This is known as the asymptotic assumption and it needs to be satisfied for conducting the Chi Square Test. The result from Table I3 highlights that only I0\% of the cells have an expected value of less than 5 thus conforming the asymptotic assumption for conducting Chi Square Test. As p-value is less than 0.05 (95\% confidence level or 5\% significance level) and statistically significant, we reject the null hypothesis and accept alternate hypothesis that there is an association between the duration the organization is using the social media platforms and the awareness of the different options of crowdfunding to raise pre-seed capital. The Cramer's $\mathrm{V}$ value of 0.869 from Table 13 propels that the association is strong. We find that respondents who stated that their organization has been using the social media platforms for a longer duration claimed to be aware of different options of crowdfunding to raise pre-seed capital compared to their counterparts whose organization has been using social media platforms recently.

Table I3. Results from Association Analysis

\begin{tabular}{llcc}
\hline \multicolumn{2}{c}{ Symmetric Measures } & Value & Approx. Sig. \\
\hline \multirow{2}{*}{ Nominal by Nominal } & Phi & I.504 & .000 \\
\cline { 2 - 4 } & Cramer's V & .869 & .000 \\
\hline N of Valid Cases & & 500 & \\
\hline
\end{tabular}

The traditional mode of finance has failed to address the challenge of fund-raising at pre-seed capital stage whereas the new mode of entrepreneurial finance like crowd-funding has the potential to solve this delinquency. The present study has created a roadmap for the entrepreneurs that will ultimately help them to raise capital at their pre-seed stage leveraging digital media and will automatically help in reducing the exit rate of start-ups which in one of the biggest snags in the domain of entrepreneurial finance. India has witnessed a paradigm shift in marketing with the emergence of social media marketing. Digital visibility has transformed the dynamics of entrepreneurship over time. Besides product selling, concept selling has developed into an integral part of entrepreneurship which has turned out to be easier through social media marketing. Many young entrepreneurs have started using the online platform/ social media marketing to approach the crowd as their fundraising activities. It has been found that though there are different modes of raising capital from angel investors, venture capitalists, and bank loans that are available in the market, yet, these options are not always effective enough to raise pre-seed capital. Crowdfunding as a mode of finance has the potential to bridge the demand and supply gap for the Indian Start-up at the nascent stage of the business that ultimately helps in improving start-ups exit.

In this study, we explored the relationship between the usage of social media and awareness of crowdfunding as a viable option for raising pre-seed capital in an emerging market of India. The results of the study suggest that awareness of different options of crowd-funding for raising pre-seed capital is strongly correlated with the effective usage of social media 
platforms by the organizations. From an organization's perspective, it has been found that effective use of Social Media platforms increases with the duration involved in social media platforms. The results of the study give a perspective for all entrepreneurs, managers and start-up companies who would like to explore crowd-funding as a source of finance in an emerging market like India. Crowd-funding and social media marketing linkage would create new dimension in the area of digital marketing and entrepreneurial finance.

\section{Conclusion}

The linkage between crowdfunding and social media is very strong yet very few studies in the literature have attempted to explore this relation empirically. Social media marketing has already started playing a significant role in emerging economies like India. Social media marketing constantly creates a platform where idea can be sold effortlessly and effectively to the crowds that eventually endorses crowdfunding. The results of the study suggest that awareness of different options of crowd-funding for raising pre-seed capital is strongly correlated with the effective usage of social media platforms by the organizations. From an organization's perspective, it has been found that effective use of Social Media platforms increases with the duration involved in social media platforms.

The results of the study give a perspective for all entrepreneurs, fundraisers, and start-up companies who would like to explore crowd-funding as a source of finance in an emerging market like India. With an emerging trend of today's youth using social media worldwide, the association between crowd-funding and social media marketing is expected to grow exponentially in terms of their contribution to the economy, wealth generation, and job creation. The present study has wrought a roadmap for entrepreneurs that will ultimately help them raise pre-seed while increasing digital visibility through social media usage and involuntarily helping in reducing the exit rate of start-ups which is one of the biggest problems today in India.

Though crowdfunding is still in the nascent stage in developing countries like India, it has the potential to solve the issue of fund-raising for entrepreneurs at their pre-seed stage. Crowdfunding and fund raising could be a catalyst to nurture diverse ideas of budding entrepreneurs and transform the same to a viable venture touching lives and in turn creating a conductive, self-sustained and transparent platform supporting the economy, wealth creation and employment in years and decades to come. The current study included only entrepreneurs from the city of Bangalore, Karnataka State, India. Further studies can be conducted using a larger sample and considering entrepreneurs across the country and different geographical regions. Future studies may also focus on measuring the effectiveness of different social media platforms once it is implemented from an organizations strategic perspective.

\section{References}

Agrawal, A., Catalini, C., \& Goldfarb, A. (20II). The geography of crowd funding (NBER Working Paper No. I6820). Retrieved March 25, 2020, from http://www.nber.org/papers/wI6820

Agrawal, A., Catalini, C., \& Goldfarb, A. (2013). Some simple economics of crowd funding (NBER Working Paper No. wI9I33). Retrieved August 6, 2020, from http://www.nber.org/papers/wI9I33

Allison, T. H., Davis, B. C., Short, J. C., \& Webb, J. W. (20I4). Crowdfunding in a pro social micro lending environment: Examining the role of intrinsic versus extrinsic cues. Entrepreneurship Theory and Practice, 39(I), 53-73.

Andreas,W., Merete, H., \& Kalanit, E. (2019). It Is Not All About Money: Obtaining Additional Benefits Through Equity Crowdfunding, The Journal of Entrepreneurship, 28(2), 270-294.

Belleflamme, P., Lambert, T., \& Schwienbacher, A. (2010). Crowdfunding: An industrial organization perspective. Prepared for the Workshop Digital Business Models: Understanding Strategies, Paris, June 2010.

Belleflamme, P., Lambert, T., \& Schwienbacher, A. (2013). Crowdfunding: Tapping the right crowd. Journal of Business Venturing, 29(5), 585-609.

Bawre, S., \& Kar, S. (2019). Social media and financial institutions in the Indian context. International Journal of Economics and Business Research, I8(3), 343-355.

Berkovich, E. (20II). Search and herding effects in peer-to-peer lending: Evidence from prosper.com. Annals of Finance, 7(3), 389-405.

Buttice, V., Colombo, M. G., \& Wright, M. (2017). Serial crowdfunding, social capital, and project success. Entrepreneurship Theory and Practice, 4I(2), I83-207.

Block, J., Vries, G. D., Schumann, J., \& Sandner, P. (2013). Trademarks and venture capital valuation. Journal of Business Venturing, 29(4), 525-542.

Burtch, G., Ghose, A., \& Wattal, S. (2013). An empirical examination of the antecedents and consequences of contribution patterns in crowd-funded markets. Information Systems Research, 24(3), 499-519. Retrieved from http://pubsonline.informs.org/doi/abs/ I0.1287/isre.I I20.0468

Choy, K., \& Schlagwein, D. (2016). Crowdsourcing for a better world: On the relation between IT affordances and donor motivations in charitable crowdfunding. Information Technology \& People, 29(I), 22I-247.

Dominik, D., Nikolaus L., Philipp., \& Jan, M. (2020). The potential of collective intelligence and crowdsourcing for opportunity creation. International Journal of Entrepreneurial Venturing. 12(2).

Everett, C. (2010). Group membership, relationship banking and loan default risk: The case of online social lending (SSRN Working Paper No. II I4428).

Economic Survey. (2019). Retrieved from https://www.indiabudget.gov.in/economicsurvey/doc/echapter.pdf 
Gerber, E. M., Hui, J. S., \& Kuo, P. Y. (2012). Crowdfunding: Why people are motivated to post and fund projects on crowdfunding platforms. Proceedings of the international workshop on design, influence, and social technologies: Techniques, impacts and ethics. Vol. 2. (pp. I0). IL: Northwestern University Evanston No. II.

Hekman, E., \& Brussee, R. (2013). Crowdfunding and online social networks. Retrieved May I5, 2018, ttp://www2.mmu.ac.uk/media/mmuacuk/content/documents/carpe/20I3conference/papers/entrepreneurship/Erik Hekman, Rogier Brussee.pdf

Heminway, J. (2014). Investor and market protection in the crowd funding era: Disclosing to and for the 'Crowd'. Vermont Law Review, 38, 827-848. Retrieved from http://papers.ssm.com/sol3/papers.cfm?abstract_id=2435757

Kleemann, F., Vob, G. G., \& Rieder, K. (2008). Un(der)paid Innovators: The Commericial Utilization of Consumer Work through Crowdsourcing. Science, Technology and Innovation Studies, 5-26.

Kaplan, A. M., \& Haenlein, M. (2010). Users of the world, unite! The challenges and opportunities of Social Media. Business horizons, 53(I), 59-68.

Lynda, Y., \& Black, S. L. (2018). US Equity Crowdfunding: A Review of Current Legislation and A Conceptual Model of the Implications for Equity Funding. The Journal of Entrepreneurship, 27(I), 83-II0.

Mihardjo, L. W. W., Sasmoko, Alamsjah, F., \& Elidjen. (2019). Digital transformation: a transformational performancebased conceptual model through co-creation strategy and business model innovation in the Industry 4.0 in Indonesia. International Journal of Economics and Business Research, I8(3), 369-386.

Mollick, E. (2013). Swept away by the crowd? Crowdfunding, venture capital, and the selection of entrepreneurs (SSRN Working Paper No. 2239204). Retrieved April I0, 2019, from http://papers.ssm.com/sol3/papers.cfm?abstract_id=2239204

Mollick, E. (20I4). The dynamics of crowdfunding: An exploratory study. Journal of Business Venturing, 29(I), I-I6.

Mollick, E., \& Nanda, R. (2016). Wisdom or madness? Comparing crowds with expert evaluation in funding the arts. Management Science, 62(6), I533-I553.

Mollick, E., \& Kuppuswamy, V. (20I4). After the campaign: Outcomes of crowdfunding (UNC Kenan-Flagler Research Paper No. 2376997).

Robiady, N. D., Windasari, N. A., \& Nita, A. (2020). Customer engagement in online social crowdfunding: The influence of storytelling technique on donation performance. International Journal of Research in Marketing.

\section{Copyrights}

Copyright for this article is retained by the author(s), with first publication rights granted to the journal. This is an openaccess article distributed under the terms and conditions of the Creative Commons Attribution license (http://creativecommons.org/licenses/by/4.0/). 